\title{
Zucchini (Cucurbita pepo L.) Cultivation in India: A Review
}

\section{Dhiraj Bhattacharjee}

Department of Horticulture, Assam Agricultural University, Jorhat-785 013, Assam, India.

Received: August 2021

Accepted: December 2021

\section{ABSTRACT}

Background: Zucchini (Cucurbita pepo L.) belong to the family Cucurbitaceae and is an exotic crop grown in both open field and protected conditions. It is recently been popularized in India due to yield and health benefits and grown in various climatic and soil conditions.

Methods: This crop is raised initially in polybags in Jorhat and Darrang of Assam and then transplanted in polythene mulched field conditions. It is grown from March-April in mild summers of North India and grows from September to December in lower hills or plains according to package of practice.

Result: Various location specific spacing and fertilizers are incorporated in this crop and growth regulators like Ethrel are incorporated to promote the number of female flowers. This crop can provide huge income revenue if exported in near future.

Key words: Cucurbitaceae, Ethrel, Mulch, Polybags.

Zucchini (Cucurbita pepo. L) or summer squash is an exotic vegetable which has recently been popularized in India. It is also called as Vegetable Marrow, Field Pumpkin in various regions of the world. Zucchini which belongs to family Cucurbitaceae is a quick growing and high yielding cucurbit which is suitable for production throughout India. It was originated in America and north-eastern Mexico and is considered as the only annual Bush type cucurbit in the world for human consumption. The plant has trailing habit and shortened internodes and can set fruits in closed succession. Fruits are botanically called Pepo and can be harvested in 50-60 days after sowing. Zucchini is mostly monoecious but there are instances of androecious mutants (Mukunda et al.).

Zucchini has various health benefits to human as well as medicinal potentials (Mohammad et al., 2011). Zucchini is considered to one of the low calorie vegetable $(17 \mathrm{Kcal}$ per $100 \mathrm{gm}$ ) and doesn't contain saturated fats or cholesterol and its peel is considered an excelled source of fibre which prevents colon cancers and manage symptoms of diabetes and protect heart health, beside it helps to prevent inflammatory conditions. Fresh fruits provide Vitamin-A upto $200 \mathrm{IU}$ per $100 \mathrm{gm}$ a significant amounts of vitamins $C, E$ and $B 6$, niacin and thiamin, as well as minerals, in terms potassium, magnesium, phosphorus, calcium, iron and manganese. Golden Skin types are rich in flavanoids, antioxidants such as carotenes, lutein and zeaxanthins.

Zucchini cultivation was done under Jorhat and Darrang of Assam conditions. Zucchini is grown in wide range of climatic conditions across India and temperature can affect the percentage and the rate of germination. Base tem-perature for summer squash (Cucurbita pepo L.) is $10^{\circ} \mathrm{C}$ while maximum growth is gained between $20^{\circ} \mathrm{C}$ to $25^{\circ} \mathrm{C}$ and ceiling temperature is $32^{\circ} \mathrm{C}$ summer squash requires cooler temperature at night than during day (Mohammad Bannayan et al., 2011).

It is cultivated in wide range of soil but thrives best in well drained fertile sandy loam soil (Bielinski et al., 2006). Soil must be rich in organic matter and good drainage facilities must be present in the fields. Early sowings are done on light soils and late sowings are favored in heavier soils (Ng'etich et al. 2013).

Seeds are sown in polybags or nursery raised and is transplanted to main field at 15-20 days after sowing (Narke et al. 2015). Rapid germination and vigorous growth occurs when soil temperature reaches from 28 to $32^{\circ} \mathrm{C}$ (Castro et al., 2011). Zucchini is sown in black polythene mulch which reduces the incidence of weeds in the fields (Kostoval et al 2014). Seed rate of approximately $1-1.25 \mathrm{~kg}$ per acre is used for sowing and optimum spacing is maintained among plants (Karde et al., 2014).

In North India where summers are mild especially in hills sowing is done from March- April and crop matures in May-June (Panse et al. 1985).

In lower hills sowing is confined to later September and continues up to December (Hamad et al., 2010). In North East Plains sowing is mainly confined to November and continues up to January. Summer squash variety Cora F1 planted in mid February gave the highest yield followed by Chungma Zucchini under the low hill conditions (Dev 2011). Varieties like cora, cheongma zucchini, champion, ASV-3098, long green, golden yellow, yellow zucchini, green star, sunny house and catherina can be easily grown as offseason field cultivation in the Tarai regions of Uttrakhand (Maurya et al., 2017). 
Spacing in crop production provides adequate sunlight, water and fertilizers between plants and weeds. Therefore it influences the crops directly and indirectly on better vegetative growth, higher yield, good quality of fruits and higher net returns. Higher cost benefit ratio (1: 3.70) was recorded at $1.2 \times 1.2 \mathrm{~m}$ spacing level in under open field condition and polyhouse conditions (Mukunda et al., 2019). In Konkan regions of Maharashtra, $60 \mathrm{~cm} \times 60 \mathrm{crn}$ spacing was the best treatment for the production of Zucchini (Hem Lata et al., 2017).

It influences the growth yield and quality of horticultural crops particularly on characters like colour, shape, size, taste, shelf life and processing. In a field experiment conducted in Konkan regions of Maharashtra, use of 150 $\mathrm{kg} / \mathrm{ha}$ Nitrogen, $50 \mathrm{~kg}$ ha-each Phosphorus and Potassium were incorporated. Phosphorus and Potassium are used as basal dose and nitrogen was applied in two splits i.e. 20 and 40 days after first dose (Hem Lata et al., 2017). Potassium foliar application increased the number of pistillate flowers, as well as yield and fruit quality (Mohammed et al. 2011 and Fekry et al. 2016).

In summer squash (Cucurbita pepo L.) cv. Punjab Chappan Kaddu, application of (50\% of the recommended dose of chemical fertilizer + Vermi-compost@ 15t/ha) the highest gross return was observed due to maximum yield per plant, yield per plot, yield per hectare. With the application of $50 \%$ of the recommended dose of chemical fertilizers + FYM @ 25t/ha and 25\% of the recommended dose chemical fertilizer + FYM @ 25t/ha has been found the highest net returns and Benefit: cost was observed.

Use of (20-20-20) NPK balanced or Nano fertilizer helps in improvement of vegetative and fruiting characteristics of the yield. There were no significant differences between this treatment and $100 \%$ mineral nitrogen fertilization treatment regarding to plant growth, mean fruit weight and early yield parameters. But it comes in the second significant grade as for total yield parameters after $100 \%$ mineral nitrogen fertilization treatment. Vegetative growth was also found to be highest on application of $5 \mathrm{mM}$ concentration of salicylic acid.

Increase in vegetative growth, leaves nitrogen content, number of female flowers, yield, as well as the physical and chemical quality of fruits can be seen when spraying squash plants with Ethrel $(250 \mathrm{ppm})$ once at the two immature leaves. Highest values of total chlorophyll, phosphorus and potassium percentage of leaves were recorded by spraying Ethrel at the age of two true leaves. Foliar spray of it had a positive effect on flowering behavior by increasing the number of female flowers in various cucurbits plants, where it more specifically in reversal the flowers from male to female (Kanawar et al., 1993).

Surface and subsurface drip on summer squash production in the sandy soils. Applying the nitrogen fertilizers through two irrigation methods (surface and subsurface drip irrigation) was more efficiency than broadcasting fertilizers. Subsurface drip irrigation has the best water distribution in the soil. The highest value of fertilizer use efficiency $(35.60 \mathrm{~kg})$ yield $/ \mathrm{kg}$ nitrogen was obtained. There are a slightly increase in crop growth, fresh yield and both of water and nitrogen use efficiency in subsurface drip more than in surface drip. (Ghany et al., 2009).

Zucchini crop is prone to fruit fly, white fly, aphids in open field conditions. Yellow sticky traps and pheromone lures traps can be used for reducing the pest incidence in open field conditions.

For better quality fruits are harvested at right stage i.e. when they reach 4 to 6 inches in length. First picking is usually done from 40-50 days after sowing and harvesting must be done before the rind begins to harden. It needs to pick every second day to maintain desirable fruit size because fruits become too large and stimulates further fruit set.

\section{CONCLUSION}

Zucchini has a huge export potential among vegetable crops due to its popularity in the western countries. But lack of research and extension facilities of this crop, the popularity and importance is scattered to some regions in India only. So by standardizing the package of practice of Zucchini will provide a tremendous scope for Vegetable growers of our country and will generate high revenue in near future.

\section{REFERENCE}

Bielinski, S., Camille, E. and Gilreath, J. (2006). Effects of Nitrogen rates on Summer squash. Proc. Fla State Hort. Soc. 119: 224-225.

Castro, G.S., Gonzalez-Hernandez, V.A., Saucedo-Veloz, C., SotoHernandez, M., Sandoval-Villa, M. and Carrillo-Salazar, Alfredo, J. (2011). Yield and quality of zucchini fruits on high doses of $\mathrm{N}$ and K. Terra Latinoamericana. 29(2): 133-142.

Dev, H. (2011). Response of summer squash varieties to planting time in lower hills of Himachal Pradesh. Agricultural Research Communication Centre. Agric. Sci. Digest. 31 (2): 106-110.

Ghany, A.M., El-Gindy, El-Shahat, El-Banna, A. Mohsen, Mohamed, F. and Metwally (2009). Effevt of fertilization and irrigation water levels on summer squash yield, irrigation and drainage. J. Agril. Eng. 26(1): 94-106.

Hamad, H.S. (2011). Effect of spacing between plants and nitrogen fertilization on flowering, growth and yield of squash. (Cucurbita pepo). Diyala Agril. Sci. J. 2(2): 239-244.

Hem Lata., Khandekar, R.G., Haldavanekar, P.C., Salvi, V.G. and Salvi, B.R. (2017). Effect of spacing and fertilizer levels on growth and yield of zucchini (Cucurbita pepo L.). International Journal of Science and Nature. 8(4): 802-805.

Kanawar, J.S., Singh, B. and Khurana, D.S. (1993). Effect of plant population and chemical fertilizers in squash melon. Indian J. Hort. 50(2): 152-157.

Karde, S.S. (2014). Effect of spacing and fertilizer levels on growth and yield of zucchini (Cucurbita pepo L.) under naturally ventilated polyhouse. M.Sc. (Hort.) Thesis, Dr. Balasaheb Sawant Konkan Krishi Vidyapeeth, Dapoli (MS).

Kostoval, D., Haytova, D. and Mechandjiev, D. (2014). Effect of type and method of fertilization on Marrows (Cucubita pepo L.) yield and fruit quality. American J. of Expt. Agril. 4(4): $376-383$. 
Maurya, Kumar, Suresh, (2017-18). Evaluation of summer squash (Cucurbita pepo L.) under protected conditions in tarai region of Uttarakhand. M.Sc. (Hort.) Thesis, G.B. Pant University of Agriculture and Technology, Pantnagar.

Mohammad, B.E., Ehsan, R., Amin, A. (2011). Climatic suitability of growing summer squash (Cucurbita pepo L.) as a medicinal plant in Iran. Not Sci. Biol. 3(2): 39-46.

Mukunda, G.K. (2019). Standardization of spacing for zucchini (Cucurbita pepo L.) under polyhouse and open field conditions. M.Sc. (Hort.) Thesis, University of Agricultural Sciences. GKVK Bengaluru.

Narke, S.R., Parulekar, Y.R., Haldavanekar, P.C., Haldankar, P.M., Dhopawkar, R.V. and Hinge, S.S. (2015). Effect of spacing and fertilizer levels on growth and yield of Zucchini (L.) under konkan Agro- climatic Conditions. J. of the Indian Society of Coastal Agricultural Research. 33(2): 22-27.

Ng'etich, O.K., Niyokuri, A.N., Rono, J.J., Fashaho, A. and Ogweno, J.O. (2013). Effect of different rates of nitrogen fertilizer on the growth and yield of zucchini (Cucurbita pepo cv. Diamant L.) Hybrid F1 in Rwandan high altitude zone. Int. Journal of Agriculture Crop Science. 5(1): 54-62.

Panse, V.G. and Sukhatme, P.V. (1985). Statistical Methods for Agriculture Workers. ICAR, New Delhi. Scholarly Journal of Agriculture Science. 3(8): 325-330. 